\title{
PENGARUH MOTIVASI DAN DISIPLIN KERJA TERHADAP KINERJA GURU SD DI KABUPATEN CILACAP
}

\author{
Apriliya Dwi Astuti \\ Program Studi Manajemen Pendidikan, Pascasarjana Universitas Negeri Surabaya \\ asfari417@gmail.com
}

\begin{abstract}
Abstrak
Motivasi adalah hal yang menyebabkan, menyalurkan, dan mendukung perilaku manusia, supaya mau bekerja giat dan antusias mencapai hasil yang optimal. Penelitian ini bertujuan untuk menganalisis pengaruh motivasi dan disiplin kerja secara bersama-sama dan parsial terhadap kinerja guru SD di Kabupaten Cilacap. Penelitian ini termasuk penelitian ex post facto dengan pendekatan kuantitatif, penarikan sampel menggunakan Proportional Cluster Random Sampling dan Analisis data dengan Analisis regresi berganda. Berdasarkan hasil penelitian dan pembahasan dapat disimpulkan bahwa terdapat pengaruh positif motivasi secara parsial terhadap kinerja guru, disiplin kerja secara parsial tidak berpengaruh terhadap kinerja guru, dan terdapat pengaruh yang signifikan secara simultan motivasi dan disiplin kerja terhadap kinerja guru SD di Kabupaten Cilacap. Upaya meningkatkan motivasi dan displin kerja perlu dilakukan secara bersama-sama dalam meningkatkan kinerja guru

Kata kunci: motivasi, disisplin kerja, kinerja guru
\end{abstract}

\section{EFFECT OF MOTIVATION AND DISCIPLINE WORK ON THE PERFORMANCE OF PRIMARY SCHOOL TEACHERS IN CILACAP DISTRICT}

\author{
Apriliya Dwi Astuti \\ Program Studi Manajemen Pendidikan, Pascasarjana Universitas Negeri Surabaya \\ asfari417@gmail.com
}

\begin{abstract}
Motivation is the thing that causes, distributes, and supports human behavior, in order to work hard and enthusiastically achieve optimal results. This study aims to analyze the influence of motivation and work discipline together and partially to the performance of elementary school teachers in Cilacap regency. This research includes ex post facto research with quantitative approach, sampling using Proportional Cluster Random Sampling and Data Analysis with multiple regression analysis. Based on the results of research and discussion can be concluded that there is a positive influence of partial motivation on teacher performance, work discipline partially does not affect the performance of teachers, and there is a significant influence simultaneously motivation and work discipline on the performance of elementary school teachers in Cilacap regency. Efforts to improve motivation and work discipline need to be done jointly in improving teacher performance.
\end{abstract}

Keywords: motivation, discipline work, teacher performance 


\section{Pendahuluan}

Pendidikan merupakan sarana penting dalam mengembangkan sumber daya manusia (SDM) dan watak bangsa (Nation Character Building), karena harkat dan martabat suatu bangsa sangat ditentukan oleh mutu pendidikannya. Menurut Undang-Undang Sisdiknas Nomor 20 tahun 2003 tentang Sistem Pendidikan Nasional pendidikan bahwa pendidikan adalah usaha sadar dan terencana untuk mewujudkan suasana belajar dan proses pembelajaran agar peserta didik secara aktif mengembangkan potensi dirinya untuk memiliki kekuatan spiritual keagamaan, ingin-dalian diri, kepribadian, kecerdasan, akhlak mulia, serta keterampilan yang diperlukan dirinya, masyarakat bangsa dan negara (Depdiknas, 2003).

Tujuan pendidikan nasional bangsa Indonesia yang tertera dalam pasal 3 Undang -Undang Republik Indonesia No. 20 Tahun 2003 tentang Sistem Pendidikan Nasional yaitu untuk berkembangnya potensi peserta didik agar menjadi manusia yang beriman dan bertaqwa Kepada Tuhan Yang Maha Esa, berakhlak mulia, berilmu, cakap, kreatif, mandiri dan menjadi warga negara yang demokratis serta bertanggung jawab. Salah satu sumber pendidikan adalah guru. Mengingat peran guru yang sedemikian pentingnya dalam menciptakan sumber daya manusia pendidikan yang handal maka sangatlah diperlukan guru yang memiliki kinerja baik (Depdiknas, 2003).

Menurut pasal 10 ayat 1 UndangUndang Republik Indonesia No. 14 tahun 2005 tentang Guru dan Dosen (Depdiknas, 2005), dan Peraturan Pemerintah Republik Indonesia No. 74 tahun 2008 tentang Guru dalam pasal 3 ayat (2) (Presiden RI, 2008) menyebutkan bahwa: kompetensi guru meliputi kompetensi pedagogik, kompetensi kepribadian, kompetensi sosial, dan kompetensi profesional yang diperoleh melalui pendidikan profesi. Semua kompetensi di atas harus tampak pada dokumen kurikulum (curriculum plan) yang berisi serangkaian mata pelajaran, silabus dan materi ajar, dan program kegiatan pem- balajaran yang strategis dan skenarionya disusun dalam rencana pembelajaran (Sagala, 2009, p. 158).

Berdasarkan penjabaran di atas dapat dikatakan bahwa untuk menilai kompetensi guru dapat diamati dari dokumen pembelajaran yang dibuat oleh guru yang besangkutan. Dokumen pembelajaran dimaksud dibuat dalam bentuk Rencana Pelaksanaan Pembelajaran (RPP)

Kinerja merupakan gabungan dari tiga faktor yang terdiri dari (a) pengetahuan, khususnya yang berhubungan dengan pekerjaan yang menjadi tanggung jawab atau lamanya bekerja, (b) pengalaman, tidak sekedar berarti jumlah waktu atau lamanya bekerja, tetapi berkenaan juga dengan substansi yang dikerjakan, (c) kepribadian, berupa kondisi di dalam diri seseorang dalam menghadapi bidang kerjanya, seperti minat, bakat, motivasi kerja, dan disiplin kerja (Nawawi, 2004, pp. 6465).

Tugas keprofesian guru menurut Undang-Undang No.14 Tahun 2005 tentang Guru dan Dosen pasal 20 (a) adalah merencanakan pembelajaran, melaksanakan proses pembelajaran dan mengevalasi hasil pembelajaran (Depdiknas, 2005).

Kinerja guru itu baik atau tidak tergantung faktor yang mempengaruhi kinerja guru tersebut. Kinerja merupakan gabungan dari tiga faktor yang terdiri dari (a) pengetahuan khususnya yang berhubungan dengan pekerjaan yang menjadi tanggung jawab atau lamanya bekerja,(b) pengalaman, tidak sekedar berarti jumlah waktu atau lamanya bekerja, tetapi berkenaan juga dengan substansi yang dikerjakan, (c) kepribadian, berupa kondisi di dalam diri seseorang dalam menghadapi bidang kerjanya, seperti minat, bakat, motivasi kerja, dan disiplin kerja (Nawawi, 2004, pp. 6465).

Berdasarkan data yang diperoleh dari Dinas Pendidikan Pemuda dan Olah Raga Kabupaten Cilacap bahwa jumlah guru SD dikabupaten Cilacap adalah 257 orang guru. Dari jumlah tersebut yang telah mendapatkan tunjangan profesi guru (TPG) adalah sebanyak 64 orang guru dan 
yang mendapatkan tunjangan daerah terpencil sebanyak 7 orang guru. Masih terdapat 193 orang guru SMK yang belum tersertifikasi. Dari 257 guru SMK yang ada 98 di antaranya adalah guru non-PNS dengan status sebagai guru kontrak daerah yang setiap bulannya diberi upah senilai Rp1.250.000., sebuah penghasilan yang boleh dikatakan sangat kecil jika dibandingkan dengan tuntutan hidup saat ini.

Data diatas menunjukkan 193 (75\%) guru belum menerima tunjangan profesi guru (TPG) dan gaji guru kontrak yang sangat tidak memadai sehingga diduga adanya beberapa dari guru SMK di Kabupaten Sumba Barat yang kesejahteraannya masih belum sesuai dengan harapan. Dampak dari kesejahteraan guru yang kurang memadai ini terlihat dari masih banyaknya guru yang melaksanakan pekerjaan tambahan lain disamping tugas utamanya dalam mengajar yaitu mengajar pada beberapa sekolah, berdagang kecil-kecilan di lingkungan sekolah, maupun beternak, yang mana hal-hal tersebut akhirnya akan berdampak pada kinerja guru.

Dalam hal motivasi kerja ada kecendrungan sejumah guru memiliki motivasi kerja yang rendah hal ini dapat terpantau dari keterlambatan guru dalam bekerja , masih seringnya diketemukan kelas yang kosong saat jam pelajaran berlangsung dan laporan-laporan kerja yang tidak sesuai dengan jadwal serta hal-hal lainnya yang dirasa kurang optimal.

Selain fenomena tersebut di atas, juga terdapat guru dengan motivasi kerja guru cukup baik hal ini terlihat dari tanggung jawab guru dalam melaksanakan tugas dan tanggung jawabnya di sekolah yang walaupun dengan kondisi wilayah yang cukup sulit dengan jarak jangkauan sekolah ke pusat kota berkisar antara 12-60 KM. Motivasi kerja seorang guru akan dipengaruhi oleh berbagai faktor internal dan faktor eksternal. Faktor internal antara lain prestasi, pengakuan/penghargaan, tanggung jawab, memperoleh kemajuan dan perkembangan dalam bekerja. Sedangkan faktor eksternal antara lain gaji/upah, hubungan antara pekerja, supervisi teknis, kondisi kerja, kebijaksanaan lembaga/ sekolah, dan proses administrasi sekolah (Herzberg dalam Nawawi(2004, p. 354)).

Kinerja adalah aktivitas seseorang dalam melaksanakan tugas pokok yang dibebankan kepadanya. Mengacu dari pandangan ini dapat diinterpretasikan bahwa kinerja seseorang dihubungkan dengan tugas-tugas rutin yang dikerjakannya (Uno \& Lamatenggo, 2012, p. 60).

Menurut Withmore (Uno \& Lamatenggo, 2012, p. 59), kinerja adalah suatu perbuatan, suatu prestasi, atau apa yang diperlihatkan seseorang melalui keterampilan yang nyata. Berdasarkan pandangan Withmore ini, kinerja menuntut adanya pengekspresian potensi seseorang, dan tanggung jawab/kepemilikan yang menyeluruh.

Berkaitan dengan kinerja guru, wujud perilaku yang dimaksud adalah kegiatan guru dalam proses pembelajaran yaitu bagaimana seorang guru mecencanakan pembelajaran, melaksanakan kegiatan pembelajaran, dan menilai hasil belajar.

Kinerja guru adalah kemampuan dan usaha guru untuk melaksanakan tugas pembelajaran sebaik-baiknya dalam perencanaan program pengajaran, pelaksanaan kegiatan pembelajaran dan evaluasi hasil pembelajaran (Dharma, 2008, p. 20).

Kesejahteraan dalam kamus lengkap bahasa Indonesia diartikan sebagai suatu keadaan sejahtera, keamanan, keselamatan, ketentraman, kemakmuran, kesenangan hidup dan sebagainya. Sementara dalam buku pengantar Studi Kesejahteraan Sosial Lombok Barat dijelaskan bahwa kesejahteraan merupakan suatu kondisi/keadaan yang sejahtera baik fisik, mental, maupun sosial.

Kesejahteraan guru adalah pemberian kemakmuran hidup kepada orang yang bekerja di lingkungan pendidikan, baik yang berupa material maupun spiritual sehingga terpenuhi kehidupan yang layak dan lebih baik sebagai timbal balik atau balas jasa dari tanggung jawab yang dipikulnya. Pemenuhan kesejahteraan yang memadai bagi guru akan menambah semangat dalam pekerjaannya, sehingga tim- 
bul kesadaran untuk mengembangkan dan meningkakan kualitas sumber daya yang ada pada dirinya (Samana, 1994, p. 15).

Dharma (2008, p. 167), mengatakan bahwa guru yang dianggap sejahtera adalah mereka yang melaksanakan tugasnya sebagai tenaga profesional, dan memiliki kepuasan terhadap kinerjanya. Adapun indikator kesejahteran guru adalah: (1) imbalan jasa; (2) hubungan kerja; (3) rasa aman; dan (4) kesempatan untuk pengembangan dan peningkatan diri.

Imbalan jasa merupakan salah satu faktor penentu kesejahteraan guru atau karyawan. Imbalan jasa biasa diberikan setelah melakukan sesuatu pekerjaaan, atau dapat dikatakan sebagai upah atas suatu pekerjaan yang dilakukan seseorang. Selain itu sebagai wujud nyata kepedulian pemerintah atas kejahteraan guru telah diterbitkannnya Undang-Undang No.14 Tahun 2005 tentang guru dan dosen yang salah satu diantaranya mengenai tunjangan profesi guru (TPG).

Keamanan dan kenyamanan guru dalam melaksanakan tugas dan tanggung jawabnya ditentukan salah satunya oleh hubungan/relasi yang terjadi dalam lingkungan tempat bekerja. Hubungan yang positif dan harmonis yang terjalin diantara guru dan semua elemen pendikan (kepala sekolah, sesama guru, TU, siswa dan wali murid) merupakan faktor pendukung kesejahteraan guru.

Situasi dan kondisi lingkungan tempat kerja yang aman sangat diperlukan seorang guru untuk dapat melaksanakan tugasnya dengan baik. Jika lingkungan tempat bekerja tidak menjamin keamanan guru maka berbagai hal dapat saja terjadi misalnya guru kurang bersemangat dan takut untuk bekerja.

Pelatihan adalah suatu kegiatan untuk meningkatkan kemampuan intelek-tual termasuk pengetahuan, penguasaan, penerapan dan pengembangan ilmu pengetahuan dan tehnologi para guru yang akan berdampak pada peningkatan komptensi dan kinerja guru.

Motivasi merupakan dorongan yang terdapat dalam diri seseorang unuk ber- usaha mengadakan perubahan tingkahlaku yang lebih baik dalam memenuhi kebutuhannya (Uno \& Lamatenggo, 2012). Dorongan tersebut didasrkan pada kebutuhan sesuai teori Maslow yaitu terdiri dari 5 kebutuhan (1) kebutuhan fisiologis, (2) kebutuhan rasa aman, (3) kebutuhan cinta kasih (4) kebutuhan pengharagaan (5) kebutuhan aktualisasi diri)

Kompetensi guru merupakan perpaduan antara kemampuan personal, keilmuan, teknologi, sosial, dan spiritual yang secara keseluruhan membentuk kompetensi standar profesi guru, yang mencakup penguasaan materi, pemahaman terhadap peserta didik, pembelajaran yang mendidik, pengembangan pribadi dan profesionalisme (Mulyasa, 2008). Kompetensi Pedagogik adalah kompetensi cara-cara mendidik peserta didik (Pidarta, 2007). Wujud dari kompetensi pedagogik ini harus tampak pada dokumen kurikulum (curriculum plan) yang bersisi serangkaian mata pelajaran, silabus dan materi ajar, dan program kegiatan pembelajaran yang strategi dan skenarionya disusun dalam rencana pembelajaran (Sagala, 2009, p. 158).

Berdasrakan uraian yang telah disampaikan tersebut, penelitiann ini bertujuan untuk (1) menganalisis pengaruh motivasi terhadap kinerja guru SD di Kabupaten Cilacap; (2) menganalisis pengaruh disiplin kerja terhadap kinerja guru SD di Kabupaten Cilacap.; (3) menganalisis pengaruh motivasi, dan disiplin kerja secara simultan/bersama-sama terhadap kinerja guru terhadap kinerja guru SD di Kabupaten Cilacap.

\section{Metode Penelitian}

Pendekatan yang digunakan dalam penelitian ini adalah pendekatan kuantitatif. Pendekatan kuantitatif digunakan untuk mengetahui korelasi antara variabel bebas dengan variabel terikat, yakni variabel motivasi dan disiplin kerja terhadap kinerja guru SD di Kabupaten Cilacap. Jenis penelitian yang digunakan adalah penelitian ex-post facto yakni penelitian yang bertujuan untuk mengungkap hu- 
bungan sebab akibat antarsubjek satu dengan subjek yang lain yang diteliti dengan tidak memanipulasi karena hanya mengungkap gejala-gejala yang ada atau telah terjadi.

Adapun desain penelitian seperti gambar berikut ini :

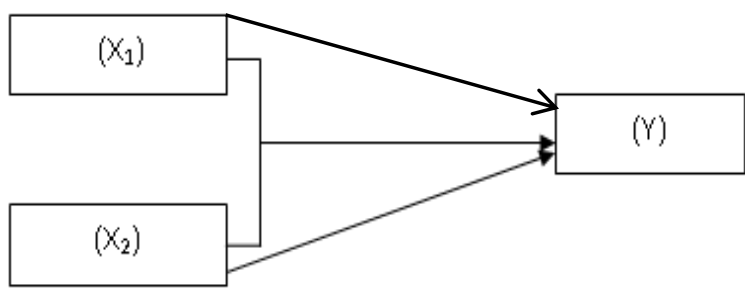

Gambar 1. Rancangan Penelitian Regresi Linier Berganda

Keterangan :

$\mathrm{H}_{1}$ : Pengaruh $\mathrm{X}_{1}$ terhadap $\mathrm{Y}$ secara sendiri

$\mathrm{H}_{2}$ : Pengaruh $\mathrm{X}_{2}$ terhadap $Y$ secara sendiri

$\mathrm{H}_{3}$ : Pengaruh $\mathrm{X}_{1}$ dan $\mathrm{X}_{2}$ terhadap $\mathrm{Y}$ secara

bersama-sama

Adapun variabel penelitian ini adalah sebagai berikut:

\section{Variabel Bebas (independent variable)}

Motivasi $\left(\mathbf{X}_{\mathbf{1}}\right)$. Pendekatan yang digunakan pada variabel motivasi guru $\left(X_{1}\right)$ untuk mendapatkan data dengan cara melakukan pemberian skor pada setiap indikator dimensi yang ada yaitu (a) kebutuhan prestasi, (b) kebutuhan penghargaan, (c) kebutuhan aktualisasi diri

Disiplin kerja $\left(\mathbf{X}_{2}\right)$.Pendekatan yang digunakan pada variable Disiplin Kerja $\left(\mathrm{X}_{2}\right)$ untuk mendapatkan data dengan cara melakukan pemberian skor kepada setiap indikator dari dimensi yang ada yaitu : ( a) ketepatan waktu, (b) kemampuan memanfaatkan dan menggunkan peluang (c) menghasilkan pekerjaan yang memuaskan, (d) mengikuti cara kerja yang ditentukan, (e) memiliki tanggung jawab yang tinggi.

\section{Variabel Terikat (dependent variable)}

Pendekatan yang digunakan pada variable kinerja guru "adakah Pengaruh" untuk mendapatkan data dengan cara melakukan pemberian skor pada setiap indikator dimensi kinerja guru yang terwujud dalam bentuk kegiatan (a) merencanakan proses pembelajaran, (b) melaksanakan proses pembelajaran (c) mengevaluasi hasil pembelajaran

Populasi dalam penelitian ini adalah semua guru SD di Kabupaten Cilacap tahun pelajaran 2016/2017 sebanya 11.410 orang guru. Teknik penarikan sampel dalam penelitian ini menggunakan Proportional Cluster Random Sampling berdasarkan Theorema Limit Sentral yaitu dengan sampel sebesar 30 telah terjadi pendekatan ke distribusi normal dari pupulasi.Jumlh sampel dalam penelitian ini adalah 71 responden. Pengumpulan data penelitian menggunakan metode angket/kuesioner, dokumentasi dan observasi.

Tabel 1. Kisi-kisi Instrumen Variabel Motivasi Kerja $\left(\mathrm{X}_{2}\right)$

\begin{tabular}{|c|c|c|}
\hline Dimensi/ Sub Variabel & Indikator & No.Sœa \\
\hline \multicolumn{3}{|c|}{ Variabel Motiv asi Kerja } \\
\hline Tanggung Jawab & $\begin{array}{l}\text { - Kerja Keras } \\
\text { - Tanggung Jawab } \\
\text { - Pencapaian tujuan } \\
\text { - Menyatu dengan tugas }\end{array}$ & $\begin{array}{l}11 ; 12 \\
13\end{array}$ \\
\hline Prestasi & $\begin{array}{l}\text { - Dorongan untuk sukses } \\
\text { - Umpan balik } \\
\text { - Unggul }\end{array}$ & $\begin{array}{l}14 ; 15 \\
16\end{array}$ \\
\hline Pengembangan diri & $\begin{array}{l}\text { - Peningkatan Ketrampilan } \\
\text { - Dorongan untuk maju }\end{array}$ & $17 ; 18$ \\
\hline Kemandirian & $\begin{array}{l}\text { - Mandiri dalam bekerja } \\
\text { - Suka pada tantangan }\end{array}$ & $19 ; 20$ \\
\hline
\end{tabular}

Tabel 2. Kisi-Kisi instrumen Variabel Kinerja Guru (Y)

\begin{tabular}{|c|c|c|}
\hline $\begin{array}{l}\text { imensisub } \\
\text { variabel } \\
\text { iabiel Kinerja }\end{array}$ & Ind ikator & No.Soal \\
\hline \multicolumn{3}{|c|}{ iabel Kinerja Guru (Y ) } \\
\hline Enyusun & a. Guru menyısun silabus sesuai kurikulum & 26 \\
\hline Program & b. Guru merancang rencana pembelajaran sesuai silabus & 27 \\
\hline \multirow[t]{8}{*}{ Peigajaran } & $\begin{array}{l}\text { c. Guru meng skuti urutan materi pelajaran dengan } \\
\text { memperhatkan tujuan pembelajarant }\end{array}$ & 28 \\
\hline & 4. Guru Memilih materi pelajaran yang: & 29 \\
\hline & 1) Sesuai dengan tujuan pem belajaran & \\
\hline & 2) Tepat dan mutakhr. & \\
\hline & 3) Sesuai dengan usia dan ting cat kemampuan & \\
\hline & belaj ar peserta didik, dan & \\
\hline & 4) Dapat dilaksenakan di kelas & \\
\hline & 5) Sesuai dengan kortekskehifupan sehari-hari & \\
\hline \multirow{4}{*}{$\begin{array}{l}\text { Menya ikan' } \\
\text { mclaksanalan } \\
\text { n progran } \\
\text { pengajaran }\end{array}$} & a Gun menjelaskan program pengajatan dengan bail: & $30 ; 31 ; 32$ \\
\hline & $\begin{array}{l}\text { b. Gun dapat ncmbcrilian il satrasi ataw contoh dalan } \\
\text { menjelaskan materi pelajaran }\end{array}$ & $33 ; 34 ;$ \\
\hline & c. Gun bersemangat dalam mengajar & 35,36 \\
\hline & d. Gun memilik wawvasan yang luas dalam & 37,38 \\
\hline \multirow{5}{*}{$\begin{array}{l}\text { Melakulkan } \\
\text { Evaluasi } \\
\text { Pengajaran }\end{array}$} & $\begin{array}{l}\text { a. Gur menyueun alat penilsian se suai tujuan pelajaran } \\
\text { dalam RPP }\end{array}$ & 39 \\
\hline & $\begin{array}{l}\text { b. Guru melaksanakan penilaian dengan berbagai tehrilk } \\
\text { penlaian }\end{array}$ & 40 \\
\hline & c. Gur menganalisis hasil penilaian & 41 \\
\hline & $\begin{array}{l}\text { d. Gin memanfaatkan masuican pe serta didik untuk } \\
\text { meningkatkan pembelaj aran selanjunya }\end{array}$ & 42 \\
\hline & $\begin{array}{l}\text { e. Gun memanfaatkan hasil penila ian sebagai bahan } \\
\text { menyusun rancangan pembelajaran selanutnya. }\end{array}$ & 43 \\
\hline
\end{tabular}




\section{Hasil Penelitian}

Hasil Uji Validitas Instrumen

Tabel 3. Hasil Uji Validitas Instrumen Kesejahteraan Guru $\left(\mathrm{X}_{1}\right)$

\begin{tabular}{|c|c|c|c|}
\hline No Item & Corrected Item-Total Correlation & Sig. & Keterangan \\
\hline $\mathrm{X}_{1.2}$ & 0.769 & 0.000 & Valid \\
$\mathrm{X}_{1.2}$ & 0.845 & 0.000 & Valid \\
$\mathrm{X}_{1 \cdot 3}$ & 0.740 & 0.000 & Valid \\
$\mathrm{X}_{1.4}$ & 0.858 & 0.000 & Valid \\
$\mathrm{X}_{1 \cdot 5}$ & 0.641 & 0.000 & Valid \\
$\mathrm{X}_{1 \cdot 6}$ & 0.804 & 0.000 & Valid \\
$\mathrm{X}_{1 \cdot 7}$ & 0.654 & 0.000 & Valid \\
$\mathrm{X}_{1 \cdot 5}$ & 0.524 & 0.003 & Valid \\
$\mathrm{X}_{1 \cdot 9}$ & 0.628 & 0.000 & Valid \\
$\mathrm{X}_{1 \cdot 10}$ & 0.763 & 0.000 & Valid \\
\hline
\end{tabular}

Berdasarkan tabel nilai hasil uji validitas variabel Motivasi di atas diketahui bahwa 15 item dari 16 item pernyataan mengenai variabel motivasi dinyatakan valid dan dapat digunakan sebagai alat penelitian kerena memiliki nilai $\mathrm{r}$ hitung lebih besar dari 0.468

Tabel 4. Hasil Uji Validitas Instrumen Motivasi Kerja $\left(\mathrm{X}_{2}\right)$

\begin{tabular}{|cccc|}
\hline No Soal & Corrected Item-Total Correlation & Sig. & Keterangan \\
\hline $\mathrm{X}_{2} \cdot 1$ & 0.875 & 0.000 & Valid \\
$\mathrm{X}_{2} \cdot 2$ & 0.880 & 0.000 & Valid \\
$\mathrm{X}_{2} \cdot 3$ & 0.835 & 0.000 & Valid \\
$\mathrm{X}_{2} \cdot 4$ & 0.797 & 0.000 & Valid \\
$\mathrm{X}_{2} \cdot 5$ & 0.826 & 0.000 & Valid \\
$\mathrm{X}_{2} \cdot 6$ & 0.911 & 0.000 & Valid \\
$\mathrm{X}_{2} \cdot 7$ & 0.840 & 0.000 & Valid \\
$\mathrm{X}_{2} \cdot 8$ & 0.867 & 0.000 & Valid \\
$\mathrm{X}_{2} \cdot 9$ & 0.891 & 0.000 & Valid \\
$\mathrm{X}_{2 \cdot 10}$ & 0.628 & 0.000 & Valid \\
\hline
\end{tabular}

Berdasarkan Tabel nilai hasil uji validitas variabel Disiplin Kerja di atas diketahui bahwa 14 dari 16 item pernyataan mengenai variabel disiplin kerja dinyatakan valid dan dapat digunakan sebagai alat penelitian karena memiliki nilai $r$ hitung lebih besar dari 0,468.

Hasil Uji Reliabilitas

Menurut Nugroho (2005, p. 114) reliabilitas suatu konstruk variabel dikatakan baik jika nilai Alpha Cronbach > 0,60. Berikut ini deskripsi reliabilias setiap variabel dapat dilihat pada Tabel 5 .

Tabel 5 menunjukan bahwa nilai reliabilitas kontruksi internal, untuk koefisien alpha masing-masing variabel Motivasi Guru $\left(X_{1}\right)$ dan Disiplin kerja $\left(X_{2}\right)$ dinyatakan reliabel karena memiliki nilai Cronbach
Alpha lebih besar dari 0,60. Dengan demikian instumen variabel motivasi dan disiplin kerja dinyatakan reliabel dan dapat digunakan dalam penelitian ini.

Tabel 5. Hasil Uji Reliabilitas Variabel

\begin{tabular}{|cccc|}
\hline Variabel & Alpha & Alpha & Kesimpulan \\
\hline Kesejahteraan Guru $\left(\mathrm{X}_{1}\right)$ & 0.899 & 0.6 & Reliabel \\
Motivasi Guru $\left(\mathrm{X}_{0}\right)$ & 0.952 & 0.6 & Reliabel \\
\hline Sumber: Lampiran 5, data diolah & & &
\end{tabular}

Deskripsi Variabel Penelitian

Tabel 6. Deskriptif Variabel Kesejahteraan Guru

\begin{tabular}{|lrc|}
\hline Kesejahteraan Guru & Mean & Kategori \\
\hline 1. Imbalan Jasa & 2.58 & Baik \\
\hline 2. Rasa Aman & 2.78 & Baik \\
\hline 3. Hubungan Antar Pribadi & 2.88 & Baik \\
\hline 4. Kesempatan untuk Pengembangan dan Peningkatan Diri & 2.59 & Baik \\
\hline \multicolumn{1}{|c|}{ Mean Kesejahteraan Guru } & $\mathbf{2 . 7 1}$ & Baik \\
\hline Sumber: lampiran 3 & &
\end{tabular}

Berdasarkan Tabel 6 dapat diketahui bahwa pada indikator berprestasi memiliki nilai rata-rata sebesar 2,81 dikatergorikan mempunyai nilai tinggi, indikator mendapat penghargaan yang peroleh guru dalam lingkungan kerja mempunyai nilai sebesar 2,71 yang dikategorikan tinggi, pada indikator aktualisasi diri nilai rata-rata sebesar 2,88 dengan katergori tinggi. Berdasarkan deskripsi kategori nilai indikator variabel motivasi guru di atas dapat disimpulkan bahwa indikator yang paling dominan dalam variabel motivasi guru adalah indikator aktualisasi diri karena memiliki skor nilai yang paling tinggi yaitu 2,88 . Secara umum motivasi guru memiliki nilai rata-rata sebesar 2,80 dengan kategori tinggi.

Tabel 7. Deskriptif Variabel Motivasi Kerja

\begin{tabular}{|lcl|}
\hline \multicolumn{1}{|c}{ Motivasi Kerja } & Mean & \multicolumn{1}{c|}{ Kategori } \\
\hline 1. Tanggung Jawab & 3.25 & Baik \\
\hline 2. Prestasi & 3.27 & Sangat Baik \\
\hline 3. Pengembangan diri & 3.29 & Sangat Baik \\
\hline 4 Kemandirian & 32.3 & Raik \\
\hline \multicolumn{1}{|c|}{ Mean } & 3.26 & Sangat Baik \\
\hline
\end{tabular}

Berdasarkan Tabel 7 di atas dapat diketahui bahwa pada indikator ketepatan waktu memiliki nilai rata-rata sebesar 2,85 dikatergorikan mempunyai nilai tinggi, indikator kemampuan menggunakan dan memanfaatkan peluang mempunyai nilai 
sebesar 2,98 yang dikategorikan tinggi, indikator menghasilkan pekerjaan yang memuaskan memiliki nilai rata-rata sebesar 2,83 dengan katergori tinggi, selanjutnya pada indikator mengikuti cara kerja yang ditentukan memiliki nilai rata-rat sebesar 3,42 dengan kategori sangat tinggi dan indikator memiliki tanggung jawab yang tinggi memiliki rata-rata sebesar 3,50 dengan kategori sangat tinggi. Berdasarkan deskripsi kategori nilai indikator variabel disiplin kerja di atas dapat disimpulkan bahwa indikator yang paling dominan dalam variabel disiplin kerja adalah memiliki tanggung jawab yang tinggi karena memiliki skor nilai yang sangat tinggi yaitu 3,50. Secara keseluruhan disiplin kerja mempunyai nilai rata-rata sebesar 3,11 dengan kategori sangat tinggi.

Tabel 8. Deskriptif Variabel Kinerja Guru

(Y)

\begin{tabular}{|ccc|}
\hline Kinerja & Skor & Kategori \\
\hline 1. Menyusun Program Pengajaran & 79.2 & Sangat Baik \\
\hline 2. Menyajikan/ melaksanakan program pengajaran & 78.1 & Sangat Baik \\
\hline 3. Melakukan Evaluasi Pengajaran & 80.3 & Sangat Baik \\
\hline Mean Skor Kinerja & 79.2 & Sangat Baik \\
\hline Sumber: lampiran 3 diolah & & \\
\hline
\end{tabular}

Berdasarkan 8 dapat diketahui bahwa pada indikator Perencanaan Pembelajaran memiliki nilai rata-rata sebesar 3,42 dikategorikan mempunyai sangat baik, indikator Pelaksanaan Pembelajaran sub indikator kegiatan pendahuluan mempunyai nilai rata-rata sebesar 3,40 yang dikategorikan sangat tinggi, indikator pelaksanaan pembelajaran sub indikator kegiatan inti memiliki nilai rata-rata sebesar 3,39 dan indikator Pelaksanaan Pembelajaran sub indikator kegiatan penutup mempunyai nilai rata-rata sebesar 3,38 dengan katergori sangat tinggi. Berdasarkan deskripsi kategori nilai indikator variabel Kinerja Guru (Y) di atas dapat disimpulkan bahwa indikator yang paling dominan dalam variabel Kinerja Guru adalah perencanaan pembelajaran karena memiliki skor nilai yang paling tinggi yaitu 3,42 dengan kategori sangat tinggi. Adapun rata-rata kinerja guru SD di Kabupeten Cilacap adalah sebesar 3,40 dengan kategori sangat tinggi.
Tabel 9. Deskripsi Persentase Kategori Kinerj GURU

\begin{tabular}{|cccc|}
\hline No & Kategori & Jumlah & Prosenta se \\
\hline 1. & Buruk & 3 & $4,62 \%$ \\
\hline 2. & Cukup & 7 & $10,77 \%$ \\
\hline 3. & Baik & 10 & $15,38 \%$ \\
\hline 4. & Sangat Baik & 45 & $69,23 \%$ \\
\hline & Total & $\mathbf{6 5}$ & $\mathbf{1 0 0} \%$ \\
\hline
\end{tabular}

Dari 65 sampel diketahui bahwa yang berkinerja sangat baik 45 orang (69.2\%), sedangkan guru yang memiliki kinerja yang baik ada 10 orang (15.4\%), dan yang memiliki kinerja cukup ada 7 orang (15.4\%), dan sisanya hanya ada 3 orang $(4.6 \%)$ guru yang memiliki kinerja yang buruk.

Hasil Uji Klasik

Tabel 10. Uji Normalitas

\begin{tabular}{|lc|}
\hline & Unstand ardized Residual \\
\hline Kolmogorov-Smifnov Z & 0,929 \\
\hline Asymp. Sig (2-tailed) & 0,354 \\
\hline Sumber: Lampiran 6 &
\end{tabular}

Berdasarkan Tabel 10 dapat dilihat bahwa nilai siginifikansi hasil uji normalitas sebesar o,354 yang artinya nilai signifikansinya $>0,05$, sehingga $\mathrm{H}_{0}$ diterima dan dapat disimpulkan bahwa residual berdistribusi normal

Tabel 11. Uji Multikolinieritas

\begin{tabular}{|lcc|}
\hline \multirow{2}{*}{ Variabel } & \multicolumn{2}{c|}{ Coilinearity Statistics } \\
\cline { 2 - 3 } & Tolerance & VIF \\
\hline Kesejahteraan Gurv $\left(\mathrm{X}_{1}\right)$ & 0,753 & 1,232 \\
\hline Motivasi Gun $\left(\mathrm{X}_{2}\right)$ & 0,995 & $1,0) 4$ \\
\hline Kompetensi Guv $\left(\mathrm{X}_{3}\right)$ & 0,753 & 1,320 \\
\hline
\end{tabular}

Sunber: Lampiran 6

Dari data Tabel 11 dapat diketahui bahwa variabel Kesejahteraan guru, Mautivasi Kerja dan Kompetensi Guru masingmasing mempunyai nilai VIF sebesar 1,232; 1,004; dan 1,320 yang mana nilai-nilai tersebut $<10$, sehingga dapat disimpulkan bahwa diantara ketiga variabel bebas tersebut tidak terjadi multikolinieritas sehingga data dapat digunakan sebagai alatpenelitian.

Berdasarkan Tabel 12 di atas dapat diketahui dari hasil uji Glejser masing-masing variabel independent memiliki nilai sig lebih besar dari 0,05 yang berarti terima $\mathrm{H}_{0}$ atau tidak terjadi Heteroskedastisitas. Jadi, model regresi linier berganda terbebas dari asumsi klasik heteroskedastisitas dan layak digunakan dalam penelitian. 
Tabel 12. Uji Heterokedastisitas

\begin{tabular}{|lcc|}
\hline \multicolumn{1}{|c}{ Variabel } & T & Sig \\
\hline Kesej ahteraan Guru $\left(\mathrm{X}_{1}\right)$ & 1,478 & 0,145 \\
\hline Motivasi Guru $\left(\mathrm{X}_{2}\right)$ & 0,269 & 0,789 \\
\hline Kompetensi Guru $\left(\mathrm{X}_{3}\right)$ & $-1,293$ & 0,201 \\
\hline
\end{tabular}

Pengujian Regresi Linier Berganda

Analisis data yang digunakan dalam penelitian ini adalah regresi linear berganda yang digunakan untuk mengetahui ada tidaknya pengaruh Kesejahteraan Guru $\left(X_{1}\right)$, Motivasi Kerja $\left(X_{2}\right)$, dan Kompetensi Guru $\left(\mathrm{X}_{3}\right)$ terhadap Kinerja Guru $(\mathrm{Y})$.

Tabel 13. Hasil Analisis Regresi Linier Berganda

\begin{tabular}{|lcc|}
\hline \multicolumn{1}{|c}{ Model } & Unstandardized Coefficients \\
& $\boldsymbol{B}$ & Std. Error \\
Constant & 0,143 & 1,085 \\
\hline Kesejahteraan Guru $\left(\mathrm{X}_{1}\right)$ & 0,317 & 0,172 \\
\hline Motivasi Kerja $\left(\mathrm{X}_{2}\right)$ & 0,248 & 0,307 \\
Kompetensi Guru $\left(\mathrm{X}_{3}\right)$ & 0,519 & 0,114 \\
\hline Sumber: Lampiran 7 & \multicolumn{3}{|}{} \\
\hline
\end{tabular}

Berdasarkan tabel di atas diperoleh persamaan regresi linier berganda yang signifikan sebagai berikut :

$$
Y=0.143+0.317+0.248+0.519
$$

$\boldsymbol{Y}=$ Kinerja Guru

$\boldsymbol{a}=$ Koofisien regresi (0.143)

$X_{1}=$ Kesejahteran Guru $(0,317)$

$X_{2}=$ Motivasi Kerja $(0,248)$

$X_{3}=$ Kompetensi Guru $(0,519)$

Dari persamaan regresi diatas dapat ditarik kesimpulan sebagai berikut. Pertama, Nilai konstanta $\left(\beta_{0}\right)$ akan bernilai sama dengan nilai Kinerja Guru (Y) sebesar 0,143 jika Kesejahteraan Guru $\left(X_{1}\right)$, Motivasi Kerja $\left(X_{2}\right)$, dan Kompetensi Guru $\left(X_{3}\right)$ bernilai konstan atau sama dengan nol.

Kedua, nilai koefisien Kesejahteraan Guru $\left(\beta_{1}\right)$ sebesar 0,317 menunjukkan bahwa jika variabel Kesejahteraan Guru $\left(X_{1}\right)$ naik satu satuan, maka akan mengakibatkan peningkatan Kinerja Guru sebesar 0,317. dan diasumsikan untuk variabel Motivasi kerja dan kompetensi guru konstan atau bernilai sama dengan nol.

Ketiga, Nilai koefisien Motivasi Kerja $\left(\beta_{2}\right)$ sebesar 0,248 menunjukkan bahwa jika variabel Motivasi kerja $\left(X_{2}\right)$ naik satu satuan, maka akan mengakibatkan penurun- an Kinerja Guru sebesar 0,248 dan diasumsikan untuk variabel Kesejahteraan Guru dan Kompetensi Guru konstan atau bernilai sama dengan nol.

Keempat, nilai koefisien Kompetensi Guru $\left(\beta_{3}\right)$ sebesar 0,519 menunjukkan bahwa jika variabel Kompetensi Guru $\left(X_{3}\right)$ naik satu satuan, maka akan mengakibatkan peningkatan Kinerja Guru sebesar 0,519 dengan asumsi variabel Kesejahteraan Guru dan Motivasi kerja konstan atau bernilai sama dengan nol.

Pengujian Hipotesis

Tabel 14. Uji Parsial Uji t

\begin{tabular}{|lcc}
\hline \multicolumn{1}{|c}{ Model } & t $_{\text {bimsz }}$ & $\mathbf{t}_{\text {siz }}$ \\
\hline Kesejahteraan Guru $\left(\mathrm{X}_{1}\right)$ & 1,843 & 0,070 \\
Motivasi Guru $\left(\mathrm{X}_{2}\right)$ & 0,808 & 0,422 \\
Kompetensi Guru $\left(\mathrm{X}_{3}\right)$ & 4,557 & 0,000 \\
\hline Sumber: Lampiran 7 & &
\end{tabular}

Kesejahteraan Guru $\left(X_{1}\right)$

$$
\begin{aligned}
& \text { Ho: } \beta_{1}=0 \\
& \mathrm{H}_{1}: \beta_{1} \neq 0 \quad \text { atau }
\end{aligned}
$$

$\mathrm{H}_{0}$ : Variabel Kesejahteraan Guru $\left(\mathrm{X}_{1}\right)$ tidak berpengaruh signifikan secara parsial terhadap variabel Kinerja Guru (Y).

$\mathrm{H}_{1}$ : Variabel Kesejahteraan Guru $\left(\mathrm{X}_{1}\right)$ berpengaruh signifikan secara parsial terhadap variabel Kinerja Guru (Y).

Berdasarkan Tabel 14 besarnya nilai signifikansi variabel bebas Kesejahteraan Guru pada uji $t$ adalah 0,070 atau > 0,05. Hal ini menunjukan bahwa $\mathrm{H}_{0}$ diterima dan $\mathrm{H}_{1}$ ditolak. Sehingga Variabel bebas Kesejahteraan Guru $\left(X_{1}\right)$ tidak berpengaruh signifikan secara parsial terhadap Kinerja Guru (Y).

Motivasi Kerja $\left(\mathrm{X}_{2}\right)$

$$
\begin{aligned}
& \text { Ho: } \beta_{2}=0 \\
& \mathrm{H}_{1}: \beta_{2} \neq 0 \quad \text { atau }
\end{aligned}
$$

$\mathrm{H}_{0}$ : Variabel Motivasi Guru $\left(\mathrm{X}_{2}\right)$ tidak berpengaruh signifikan terhadap variabel Kinerja Guru (Y).

$\mathrm{H}_{1}$ : Variabel Motivasi Guru $\left(\mathrm{X}_{2}\right)$ berpengaruh signifikan terhadap variabel Kinerja Guru (Y).

Berdasarkan Tabel 14 besarnya nilai signifikansi variabel bebas Motivasi Kerja 
pada uji $\mathrm{t}$ adalah 0,422 atau $>0,05$. Hal ini menunjukan bahwa $\mathrm{H}_{0}$ diterima dan $\mathrm{H}_{1}$ ditolak. Sehingga variabel bebas Motivasi Guru $\left(X_{2}\right)$ tidak berpengaruh signifikan secara parsial terhadap Kinerja Guru $(Y)$. Kompetensi Guru $\left(\mathrm{X}_{2}\right)$

$$
\begin{aligned}
& \text { Ho }: \beta_{3}=0 \\
& H_{1}: \beta_{3} \neq 0 \quad \text { atau }
\end{aligned}
$$

$\mathrm{H}_{0}$ : Variabel Kompetensi Guru $\left(X_{3}\right)$ tidak berpengaruh signifikan terhadap variabel Kinerja Guru (Y).

$\mathrm{H}_{1}$ : Variabel Kompetensi Guru $\left(\mathrm{X}_{3}\right)$ berpengaruh signifikan terhadap variabel Kinerja Guru (Y).

Berdasarkan Tabel 14 besarnya nilai signifikansi variabel bebas Kompetensi Guru pada uji $t$ adalah 0,000 atau $<0,05$. Hal ini menunjukan bahwa $\mathrm{H}_{0}$ ditolak dan $\mathrm{H}_{1}$ diterima. Sehingga variabel bebas Kompetensi Guru $\left(X_{3}\right)$ berpengaruh signifikan secara parsial terhadap Kinerja Guru $(Y)$.

Kesimpulan yang dapat diambil dari hasil pengujian diatas adalah bahwa model regresi yang digunakan diatas dengan menggunakan uji $\mathrm{t}$ atau dengan taraf signifikan (sig.) sudah benar atau layak, dimana variabe kesejahteran guru $\left(\boldsymbol{X}_{\mathbf{1}}\right)$ dan motivasi kerja $\boldsymbol{X}_{\mathbf{2}}$ tidak mempunyai pengaruh terhadap kinerja guru $(Y)$ sedangkan kompetensi guru $\boldsymbol{X}_{\mathbf{3}}$ mempunyai pengaruh terhadap kinerja guru (Y) SMK di Kabupaten Sumba Barat.

Berdasarkan Tabel 15 dapat dilihat bahwa nilai Sig. sebesar 0,000 dimana mem- punyai nilai < dari 0,05 sehingga dapat dikatakan bahwa $\mathrm{H}_{0}$ ditolak, dengan arti variabel Kesejahteraan Guru $\left(X_{1}\right)$, Motivasi kerja $\left(X_{2}\right)$, dan Kompetensi Guru $\left(X_{3}\right)$, secara bersama-sama (simultan) memiliki pengaruh secara signifikan terhadap Kinerja Guru (Y).

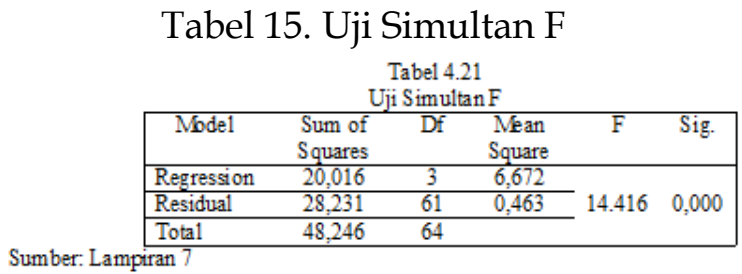

Analisis Koefisien Korelasi (R) dan Determinasi Berganda $\left(\mathrm{R}^{2}\right)$

Tabel 16. Koefisisen Determinasi

\begin{tabular}{|cccc|}
\hline $\mathbf{R}$ & $\mathbf{R}$ Square & $\begin{array}{c}\text { Adjusted } R \\
\text { Square }\end{array}$ & $\begin{array}{c}\text { Std. Error of the } \\
\text { Estimate }\end{array}$ \\
\hline 0,644 & 0,415 & 0,386 & 0,680 \\
\hline
\end{tabular}

Nilai koefisien determinasi atau $\mathrm{R}^{2}$ digunakan untuk mengukur seberapa jauh kemampuan model dalam menerangkan variasi variabel tidak bebas atau variabel bebas yaitu variabel Kinerja Guru. Hasil dari perhitungan SPSS diperoleh nilai $\mathrm{R}^{2}=$ 0,415 yang berarti bahwa sebesar $41,5 \%$ Kinerja Guru dapat dijelaskan oleh variabel Kesejahteraan Guru $\left(X_{1}\right)$, Motivasi kerja $\left(X_{2}\right)$, dan Kompetensi Guru $\left(X_{3}\right)$. Sedangkan sisanya $58.5 \%$ dipengaruhi oleh variabel lain diluar model yang diteliti.

\section{PEMBAHASAN}

\begin{tabular}{|c|c|}
\hline $\begin{array}{c}\text { Komponen } \\
\text { Evaluasi Ahli }\end{array}$ & Temuan \\
\hline $\begin{array}{l}\text { Hasil Pengujian Secara Parsial } \\
\text { Kesejahteraan Guru } \\
\text { Kesejahteraan guru berpengaruh terhadap kinerja } \\
\text { guru. } \\
\text { Kesejahteraan guru adalah pemberian } \\
\text { kemakmuran hidup kepada orang yang bekerja di } \\
\text { lingkungan pendidikan, baik yang berupa material } \\
\text { maupun spiritual sehingga terpenuhi kehidupan } \\
\text { yang layak dan lebih baik sebagai timbal balik atau } \\
\text { balas jasa dari tanggung jawab yang } \\
\text { dipikulnya.Pemenuhan kesejahteraan yang } \\
\text { memadai bagi guru akan menambah semangat }\end{array}$ & $\begin{array}{l}\text { Berdasarkan hasil analisis diketahui bahwa tidak ada } \\
\text { pengaruh signifikan kesejahteraan guru }\left(\mathrm{X}_{1}\right) \text { terhadap } \\
\text { kinerja guru }(\mathrm{Y}) \text { SD di Kabupaten Cilacap. } \\
\text { Kesimpulan yang dapat diambil adalah hipotesis pertama } \\
\text { “Terdapat pengaruh antara Kesejahteraan guru dengan } \\
\text { kinerja guru SD di Kabupaten Sumba Barat ", dinyatakan } \\
\text { ditolak dan tidak terbukti kebenarannya. } \\
\text { Temuan ini bertentangan dengan pendapat ahli dan } \\
\text { tujuan pemberiian TPG adalah untuk meningkatkan } \\
\text { kinerja guru. Hal ini jika pada sebagaian besar orang } \\
\text { menilai kesejahteraan seseorang dilihat dari seberapa besar } \\
\text { pengahasilan/ gaji yang diterima, tetapi hal ini agak }\end{array}$ \\
\hline
\end{tabular}

Tabel 17. Hasil Pengujian Hipotesis 
dalam pekerjaannya, sehingga timbul kesadaran untuk mengembangkan dan meningkakan kualitas sumber daya yang ada pada dirinya (Samana, 1994, p. 15). berbeda dengan guru SD di kabupaten Cilacap yang menilai kesejahteraaan itu tidak hanya dari seberapa besar pengahasilan/gaji yang diterima namun kepercayaan dan kesempatan untuk dapat menjadi seorang tenaga pengajar adalah suatu bentuk kesejahteraan yang tidak ternilai harganya. Karena dengan memiliki profesi sebagai seorang tenaga pengajar di Kabupaten Cilacap dapat meningkatkan status sosial seseorang. Peningkatan status sosial guru ini berdampak pada pengahargaan dalam masyarakat yang diterimanya.

Motivasi Kerja
Motivasi Kerja berpengaruh terhadap Kinerja Guru.
Motivasi merupakan dorongan yang terdapat
Hasil analisis menunjukan baha motivasi kerja tidak berpengaruh terhadap kinerja guru .

Berdasarkan hasil analisis ini maka hipotesis ke dua " Ada Pengaruh signifikan motivasi kerja terhadap kinerja guru SD di Kabupaten Cilacap“", di tolak dan tidak terbukti kebenarannya.

Hal ini disebabkan karena guru SD di Kabupaten Cilacap sudah memiliki motivasi kerja yang sangat baik sehingga dalam upaya meningkatkan kinerjanya penekanannya lebih pada aspek kompetensi yang dimiliki oleh guru SD.

Kebutuhan cinta kasih (4) Kebutuhan pengharagaan (5) Kebutuhan aktualisasi diri) $1 . \quad$ Kompetensi Guru
Kompetensi guru merupakan perpaduan antara kemampuan personal, keilmuan, teknologi, sosial, dan spiritual yang secara keseluruhan membentuk kompetensi standar profesi guru, yang mencakup penguasaan materi, pemahaman terhadap peserta didik, pembelajaran yang mendidik, pengembangan pribadi dan profesionalisme (Mulyasa, 2008). Kompetensi Pedagogik adalah kompetensi cara-cara mendidik peserta didik (Pidarta, 2007). Wujud dari kompetensi pedagogik ini harus tampak pada dokumen kurikulum ( curriculum plan) yang bersisi serangkaian mata pelajaran, silabus dan materi ajar, dan program kegiatan pembelajaran yang strategi dan skenarionya disusun dalam rencana pembelajaran (Sagala, 2009, p. 158).

\section{Hasil Pengujian Secara Simultan}

Kinerja guru dipengruhi oleh beberapa faktor diantaranya adalah kesejahteraan guru, motivasi kerja dan kompetensi guru
Hasil analisis menunjukan bahwa kompetensi guru berpengaruh signifikan terhadap kinerja guru.

Berdasarkan hasisl analisis ini maka kesimpulannya adalah hipotesis ke tiga yaitu "ada pengaruh signifikan kompetensi guru terhadap kinerja guru SD di Kabupaten Cilacap", diterima dan terbukti kebenarannya. Kedua variabel tersebut menunjukkan pengaruh positif atau terdapat hubungan searah, yang berarti semakin tinggi kompetensi yang dimiliki guru maka akan semakin tinggi pula kinerja guru tersebut.
Hasil analisis menunjukkan variabel Kesejahteraan Guru $\left(X_{1}\right)$, Motivasi Guru $\left(X_{2}\right)$, dan Kompetensi Guru $\left(X_{3}\right)$, secara simultan berpengaruh secara signifikan terhadap Kinerja Guru (Y).

Berdasarkan hasil analisis ini maka kesimpulannya adalah hipotesis ke empat " Terdapat pengaruh secara bersamasama antara kesejahteraan guru, motivasi kerja dan kompetensi guru terhadap kinerja guru SD di Kabupaten Cilacap", diterima dan terbukti kebenarannya.

\section{Simpulan}

Berdasarkan hasil analisis data dan pembahasan pada bab sebelumnya dengan menggunakan analisis regresi berganda maka dapat ditarik simpulan sebagai berikut. Pertama, ada pengaruh antara motivasi terhadap kinerja guru SD di Kabupaten Cilacap , karena guru SMK di Kabupetan Cilacap tidak menilai motivasi dari sisi besarnya gaji/imbalan jasa yang diterima.
Kedua, tidak ada pengaruh antara disiplin dengan kinerja guru SD di Kabupaten Cilacap. Semangat pengabdian yang tinggi merupakan salah satu faktor yang menunjang kinerja guru. Ketiga, ada pengaruh secara bersama-sama antara motivasi dan disiplin kerja terhadap kinerja guru SD di Kabupaten Cilacap. Dalam rangka meningkatkan kinerja guru SD di Kabupaten Cilacap maka perlu adanya peningkatan motivasi kerja dan disiplin guru. 


\section{Daftar Pustaka}

Depdiknas. Undang-Undang Nomor 20

Tahun 2003 tentang Sistem

Pendidikan Nasional (2003). Jakarta.

Depdiknas. Undang-Undang No. 14 Tahun 2005 tentang Guru dan Dosen (2005). Jakarta.

Dharma, S. (2008). Manajemen kinerja, falsafah, teori dan penerapannya. Yogyakarta: Pustaka Pelajar.

Mulyasa, E. (2008). Standar kompetensi dan sertifikasi guru. Bandung: PT Remaja Rosda Karya.

Nawawi, H. (2004). Manajemen sumber daya manusia. Yogyakarta: Gajah Mada University Pres.
Pidarta, M. (2007). Wawasan pendidikan. Surabaya: Unesa Universiyi Press.

Presiden RI. Peraturan Pemerintah RI Nomor 74 Tahun 2008 tentang Guru (2008).

Sagala, S. (2009). Konsep dan makna pembelajaran untuk membantu memecahkan problematika belajar dan mengajar. Bandung: Alfabeta.

Samana, A. (1994). Profenalisme keguruan. Yogyakarta: Hikayat.

Uno, H. B., \& Lamatenggo, N. (2012). Teori kinerja dan pengukurannya. Jakarta: Bumi Aksara. 